\title{
Coal potential of Patala Formation, Dandli area, Kotli district, Kashmir, Pakistan
}

\author{
*Shahid Jamil Sameeni and Zafar Mahmood \\ Institute of Geology, University of the Punjab, Lahore-54590, Pakistan
}

(Email: drsameeni.geo@pu.edu.pk)

\begin{abstract}
Detailed geological mapping was carried out in Dandli of the Kotli district where Middle Cambrian to Late Miocene rocks are exposed. The coal bearing Patala Formation of the Upper Paleocene epoch is well exposed on both limbs of the doubly plunging Tattapani-Karela anticline and also on the eastern plunge of the doubly plunging Devigarh-Palana anticline. These anticlines are considered as the continuation of the Riasi anticline in Jammu, India. Structurally, the Kotli area lies to the south east of the Hazara-Kashmir Syntaxis.

The $73.2 \mathrm{~m}$ thick Patala Formation contains two coal seams. The exposed thickness of individual seam ranges from $1 \mathrm{~m}$ to 1.2 $\mathrm{m}$ and in the underground, it reaches upto $4 \mathrm{~m}$ at some places. The coal from the Dandli area has medium volatiles and low moisture with generally low ash content and good fixed carbon. Sulphur content varies from 0.51 to $3.17 \%$ and occurs in the form of pyrite nodules. The chemical analyses reveal that the coal is bituminous to semi-anthracite variety.
\end{abstract}

Keywords: Patala Formation, Dandli, Hazara-Kashmir Syntaxis, Cambrian, Paleocene.

Paper Received: 10 April 2015

Paper Accepted: 14 January 2016

\section{INTRODUCTION}

Pakistan is suffering from energy crises and present level of energy generation is not enough for its present demands and industrial growth. Coal is one of the primary source of energy, it can be used in electricity generation, cement factories and brick kilns. Pakistan has huge reserves of unexplored coal, but 2.5 million metric tons of coal per year was imported for its industry. The present study area in the Kotli district is one of the potential coal fields of Pakistan situated between longitudes $73^{\circ} 57^{\prime} 54^{\prime \prime} \mathrm{E}$ to $73^{\circ} 58^{\prime} 00^{\prime \prime} \mathrm{E}$ and latitudes $33^{\circ} 32^{\prime} 00^{\prime \prime} \mathrm{N}$ to $33^{\circ}$ $32^{\prime} 25^{\prime \prime} \mathrm{N}$ (Fig. 1) where ancient style of coal mining is carried out since 1970 .

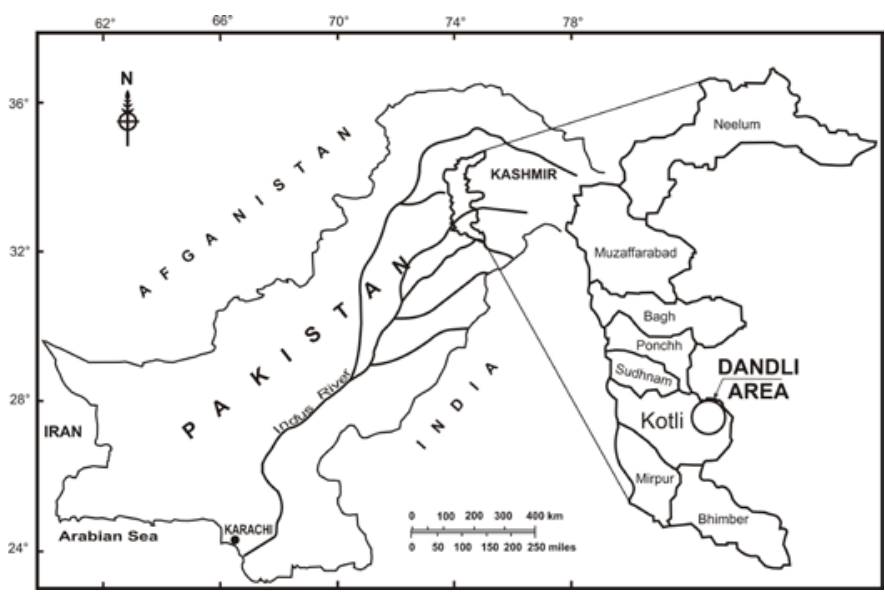

Fig. 1: Location map of study area.

Verchere (1867) is the pioneer of geological work in the Dandli area. He had worked on the fundamental geology of the Kashmir Himalaya and Afghan mountain area. Meddlicott (1876) had described the geology of Sub-Himalayan Series in Jammu Hills. Ledekker (1876) had done the basic work on the geology of the Pir Panjal and its surroundings. Wadia (1928) had described the geology of Poonch area and some parts of Punjab. Chaudhary and Ashraf (1980) had worked on the volcanic rocks of Poonch district. Ashraf et al. (1983) have established the stratigraphy of Kotli district and correlated with the geology of other areas of Pakistan. Ashraf et al. (1986) were the first one who worked on the coal of the Kotli area. Wells and Gingerich (1987) has established the paleoenvironment of Paleogene strata of this area. Present study is the first comprehensive research work of this area, in which a detailed geological mapping of the area was carried out, a stratigraphic section was measured in detail as well as samples were analysed to estimate the quality and quantity of the coal present in this area.

\section{MATERIAL AND METHOD}

Geological mapping was carried out in semi-detail scale of 1:10,000 and cross-sections were also prepared. The stratigraphic section was measured at Dandli and a detailed stratigraphic column was prepared. Coal samples were collected from different outcrops of the formation and from the mines and analysed them in the laboratory to assess its quality. The available data were also used to estimate the total quantity of the coal in this area.

\section{RESULT AND DISCUSSION}

The rocks exposed in the Dandli area are from Cambrian to Early Miocene in age. The oldest one is Abbottabad Formation of Cambrian age and the youngest one is the Murree Formation of Early Miocene age. The straitigraphic sequence is given in Table 1. 
Table 1: Stratigraphy of the Dandli area.

\begin{tabular}{|c|c|c|}
\hline Formation & Lithology & Geological Age \\
\hline Alluvium & & Recent \\
\hline $\begin{array}{l}\text { Murree } \\
\text { Formation }\end{array}$ & $\begin{array}{c}\text { siltstone, fossiliferrous } \\
\text { monotonous sequence } \\
\text { of clay }\end{array}$ & Early Miocene \\
\hline \multicolumn{3}{|c|}{----Unconformity---- } \\
\hline $\begin{array}{l}\text { Margala Hill } \\
\text { Limestone }\end{array}$ & Marl, limestone & Early Eocene \\
\hline $\begin{array}{l}\text { Patala } \\
\text { Formation }\end{array}$ & $\begin{array}{l}\text { shale, marl and } \\
\text { limestone }\end{array}$ & Late Paleocene \\
\hline \multicolumn{3}{|c|}{----Unconformity---- } \\
\hline $\begin{array}{l}\text { Datt } \\
\text { Formation }\end{array}$ & $\begin{array}{l}\text { siltstone and mudstone, } \\
\text { glass sand, fire clay }\end{array}$ & Jurassic \\
\hline \multicolumn{3}{|c|}{---Unconformity--- } \\
\hline $\begin{array}{l}\text { Abbottabad } \\
\text { Formation }\end{array}$ & $\begin{array}{l}\text { Dolomite, quartzite } \\
\text { and phyllite }\end{array}$ & Cambrain \\
\hline
\end{tabular}

In the Dandli area, the Patala Formation is directly overlying Sirban Dolomite of the Abbottabad Formation of Cambran age. The contact is unconformable and marked by bauxite/ laterite (Fig. 2). At the base, $4 \mathrm{~m}$ thick thin bedded ferruginous, grey to dark shale is exposed, followed by $1 \mathrm{~m}$ thick band of lenticular coal seam which is black with bright luster, brittle and pyritized. The sample No. 1 was collected from this point. Then $6 \mathrm{~m}$ thick ferruginous shale with little sand is exposed which is capped by $2.1 \mathrm{~m}$ thick fossiliferous limestone of greyish to brownish colour, followed by $17.9 \mathrm{~m}$ thick earthy grey shale. At the top of this shale, $1.2 \mathrm{~m}$ thick second seam of coal is exposed.

The sample No. 2 is collected from this upper coal seam. At the top of this upper coal seam $13 \mathrm{~m}$ thick greyish, fossiliferous calcareous shale is exposed with interbedded limestone followed by $3 \mathrm{~m}$ thick light grey to greyish thin bedded limestone. Then $8 \mathrm{~m}$ thick Patala Formation is covered by scree. At the top of this formation, $17 \mathrm{~m}$ thick earthy grey shale is exposed with interbedding limestone. The upper contact of the Patala Formation in this area is conformable and sharp with the Eocene Margala Hill Limestone. The coal samples No. 3 and 4 are collected from the mines of this area. All these samples were analysed in the laboratory (quantitative analysis) and results are presented in Table 2.
Table 2: Semi Quantitative Analysis coal samples from Dandi area.

\begin{tabular}{|c|c|c|c|c|c|}
\hline $\begin{array}{c}\text { Sample } \\
\text { No. }\end{array}$ & Moisture & $\begin{array}{l}\text { Volatile } \\
\text { Matter }\end{array}$ & $\begin{array}{c}\text { Carbon } \\
\text { Contents }\end{array}$ & $\begin{array}{c}\text { Ash } \\
\text { Contents }\end{array}$ & Sulphur \\
\hline 01 & 9.75 & 18.40 & 57.51 & 14.33 & 0.51 \\
\hline 02 & 11.07 & 22.67 & 53.02 & 12.83 & 0.29 \\
\hline 03 & 1.79 & 11.56 & 56.21 & 33.39 & 3.17 \\
\hline 04 & 7.04 & 29.38 & 42.18 & 21.39 & 0.34 \\
\hline 05 & 10.8 & 18.7 & 56.37 & 12.5 & 1.63 \\
\hline 06 & 9.60 & 17.29 & 63.53 & 8.40 & 1.18 \\
\hline 07 & 6.18 & 9.44 & 60.18 & 22.22 & 1.98 \\
\hline 08 & 7.72 & 10.25 & 65.01 & 15.12 & 1.9 \\
\hline 09 & 5.27 & 10.78 & 59.21 & 23.45 & 1.29 \\
\hline 10 & 13.95 & 9.64 & 61.83 & 12.80 & 1.78 \\
\hline 11 & 11.76 & 25.51 & 48.60 & 12.78 & 1.35 \\
\hline 12 & 16.55 & 23.36 & 44.83 & 13.96 & 1.3 \\
\hline 13 & 19.52 & 24.26 & 41.89 & 12.35 & 1.98 \\
\hline 14 & 7.18 & 10.44 & 58.18 & 23.22 & 0.98 \\
\hline 15 & 10.76 & 22.51 & 51.60 & 13.73 & 1.40 \\
\hline 16 & 11.80 & 17.7 & 54.37 & 14.54 & 1.59 \\
\hline 17 & 11.04 & 20.38 & 50.18 & 18.39 & 0.34 \\
\hline 18 & 10.79 & 11.56 & 56.21 & 25.39 & 1.17 \\
\hline 19 & 14.55 & 15.36 & 54.83 & 14.93 & 1.23 \\
\hline 20 & 10.27 & 14.78 & 55.21 & 18.54 & 1.20 \\
\hline
\end{tabular}

The study area is lying in the south east of HazaraKashmir Syntexis and structurally folded and faulted (Fig. 3). The coal bearing Patala Formation of the Upper Paleocene epoch is well exposed on both limbs of the doubly plunging Tattapani-Karela anticline and also on the eastern plunge of the doubly plunging Devigarh-Palana anticline. These anticlines are considered as the continuation of the Riasi anticline in Jammu, India. The occurrence of coal is shown in the cross sections along line L-M and X-Y in Fig. 3. 




Fig. 2: Stratigraphic Section of Patala Formation, Dandli area, Kotli district. 


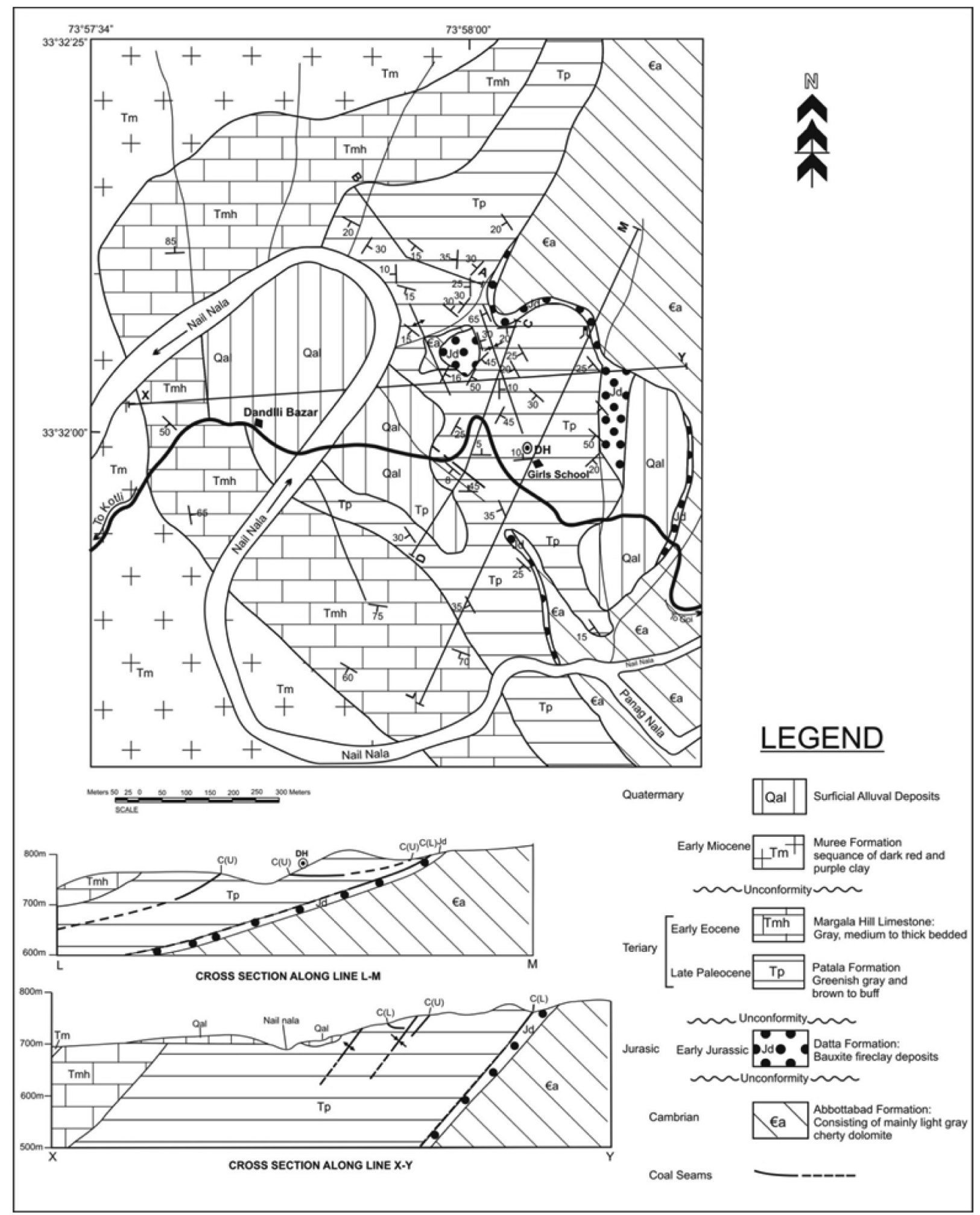

Fig. 3: Geological map of Dandli area.

\section{CONCLUSIONS}

The coal of the Dandli area has medium volatiles (sulphur, short chain/aromatic hydrocarbons etc), low moisture content, and generally low ash content with good fixed carbon (56\% in average). Sulphur content varies from 0.51 to $03 \%$ and occurs in the form of pyrite nodules. The chemical analyses reveal that coal of the Kotli district is bituminous to semi-anthracite type of coal. 


\section{REFERENCES}

Asharaf, M., Chaudhary, M. N., and Malik, R. H., 1986, Bituminous/Anthracitic coal of Kotli district, Azad Kashmir. Kashmir Jour. Geol., v. 4, pp. 1-14.

Asharaf, M., Chaudhary, M. N., and Kaleem, A. Q., 1983, Stratigraphy of Kotli area of Azad Kashmir and its correlation with standard areas of Pakistan. Kashmir Jour. Geol., v. 4, pp. 19-24.

Chaudhary, M. N. and Ashraf, M., 1980, The volcanic rocks of Poonch District, Azad Kashmir. Sp. Issue, Geol. Bull. Univ. Peshawar, v. 13, pp. 121-128.

Ledekker, R., 1876, Notes on the geology of the Pir Panjal and neighboring districts. Rec. Geol. Surv. Ind. v.9, 155 p.
Meddlicott, H.B. 1876, Notes on the sub-Himalayan series in Jammu Hills. Rec. Geol. Surv. Ind., v. 9, 49 p.

Verchere, A, 1867, On the Geology of Kashmir Himalaya and the Afghan Mountains. Jour. Asiatic Soc. Bengal, v. XXXV, Issue II, pp. 89-133.

Wadia, D. N., 1928. The Geology of Poonch state (Kashmir) and adjacent portions of the Punjab. Mem. Geol. Surv. India, v. 51, pp.185-370.

Wells, N. A. and Gingerich, P. D., 1987, Paleoenvironmental interpretation of Paleogene Strata near Kotli, Azad Kashmir, Northeastern Pakistan. Kashmir Jour. Geol., v. 5, pp. 23-42. 